\title{
Research Approach towards Formulating Research and Innovation Capacity Development Framework for Disaster Resilience in Higher Education Institutions
}

\author{
Ezri Hayat", Renuka Thakore ${ }^{\#}$, Champika Liyanage*, Richard Haigh ${ }^{\#}$, Dilanthi Amaratunga ${ }^{\#}$ \\ ${ }^{\#}$ Global Disaster Resilience Centre, University of Huddersfield, Huddersfield, HD13DH, United Kingdom \\ E-mail:e.e.hayat@hud.ac.uk \\ "School of Engineering, University of Central Lancashire, Preston, PR12HE, United Kingdom \\ E-mail:RThakore1@uclan.ac.uk
}

\begin{abstract}
The developing countries have experienced a large number of disaster events with extensive loss of life and goods. Effective mitigation and preparedness can greatly reduce the threat posed by hazards of all type. The potential of networked models to enhance the impact and efficiency of investments in disaster resilience (DR) research capacity-building in Asia; the importance of ensuring stronger local ownership of initiatives; and, the importance of building sustainable research institutions have been identified by global funders and policymakers as the priority towards strengthening the capacity of developing countries to do and use research, which is widely viewed as vital for meeting long-term innovation in creating DR societies. To fill the gap in the literature with regards to research and innovation capacity development of Higher Education Institutions (HEIs) in the disaster resilience related areas, this study formulated a capacity development framework (CDF) to help the HEIs play their roles as incubators of knowledge and ideas, and as the centre for innovation and generation of ideas. The key performance indicators and measures to assess research and innovation capacity were identified through qualitative systematic literature review and a three-round focus group discussions. Additional data was collected from 213 semi-structured interviews and 530 online survey questionnaires. The proposed capacity development framework consists of six lenses - policy, skills and training, staff, funding, infrastructure, and cross-cutting. Each lens highlights key category for current and future environment to strengthen research and innovation (R\&I) capacity for the development of societal resilience to disasters in HEIs.
\end{abstract}

Keywords - higher education; research and innovation; capacity development; disaster resilience

\section{INTRODUCTION}

With the emergence of a knowledge economy, investment in knowledge production has become a highly rewarding activity, and hence it has become an important corporate concern. Enhancing research and innovation (R\&I) capacity in Higher Education Institutions (HEIs) is becoming increasingly needed so that they can adequately play their role as incubators of knowledge and ideas. Making HEIs the centre for innovation and generation of ideas is critical for development. It is argued that there is a long division of knowledge and the developing countries suffer from a lack of human resources R\&I capacity [1], [2]. They need to improve their capacity to produce knowledge domestically and absorb knowledge produced elsewhere.

The developing countries have experienced a large number of disaster events with extensive loss of life and goods. The statistical data suggests that the three most destructive natural disasters - storms, earthquakes and flood, frequently occur in the developing countries.

A major contributory factor to disaster risk is capacity. This capacity needs to be deployed before the hazard visits a community in the form of pre-disaster planning. Effective mitigation and preparedness can greatly reduce the threat posed by hazards of all types. Likewise, capacity can also be deployed following a major disruptive event.

Global funders and policymakers have increasingly considered as key priorities: the potential of networked models to enhance the impact and efficiency of investments in disaster resilience (DR) research capacity-building in Asia; the importance of ensuring stronger local ownership of initiatives; and, the importance of building sustainable research institutions. These matters because strengthening the capacity of developing countries to do and use research are widely viewed as vital for meeting long-term innovation in creating DR societies. 
Firstly, research capacity development is one of the most critical challenges facing HEIs in the developing countries. Growing the number and quality of researchers is a strategic issue. Even though academic research have gain recognition, the supporting policies are not powerful enough to encourage academics to do research to the best of their potential [1]

Secondly, research is an important element of a successful academic career and certainly one that receives intense evaluation during hiring, performance assessments and for promotions. Developing research capacity can help enhance academic fulfilment as well as provide career advancement. Thirdly, the success of the universities depends upon having a staff that is motivated and supportive of the institutions' mission to conduct internationally-leading research. Without 'buy-in' from the staff at all levels, universities will not be competitive on the international stage.

It is identified that there is a gap in the literature with regards to assessment of R\&I capacity of HEIs, particularly with regards to research in the disaster resilience related areas. A framework to assess the R\&I capacity development is therefore required to help HEIs play their role as incubators of knowledge and ideas, and as the centre for innovation and generation of ideas. As Crossley suggests, research capacity building should not be overly-dominated by a single conception, as the educational research capacity in the diverse international context could result in maintaining dependency and hegemony than strengthening stakeholders' ownership and voice to genuinely meet the local needs [2]. This study has been accordingly undertaken to support the institutional and national capacity for societal resilience to disasters in line with the targets established by the Sendai Framework for Disaster Risk Reduction 20152030 (UNISDR, 2015).

The paper aims at elaborating the research approach used for the formulation of R\&I capacity development framework (CDF) for disaster resilience in Higher Education Institutions (HEIs). The paper will accordingly elaborate the methodologies and analysis of data collected from three case study countries, which lead to the formulation of the proposed R\&I capacity development framework.

\section{MATERIAL AND METHOD}

The development of the R\&I capacity development framework was carried-out based on four research methods and data collection series; qualitative systematic literature review, focus group discussion, semi-structured interviews, and online questionnaire survey. Each of these methods will be discussed in the following section.

\section{A. Qualitative Systematic Literature Review}

At the initial stage, the exercise was focused on the identification of research and innovation capacity indices in the literature. Google Scholar was used as the source of publications, and "innovation capacity index" and "research capacity index" were set as the search keywords. The search results were limited to publication title only by adding "Allintitle:" in the search keywords and also limited to exclude patents and citations. Publications, where full-text articles were not in English, were also excluded from further analysis. Publication duplicates were also removed to improve efficiency in data cleaning [3].

At the next step, relevant publications were analysed for the objectives, context, and the R\&I indices. Using the content analysis technique, each of these publications was further examined to identify measures relevant to the R\&I CDF. The measures included 'barriers' and 'enablers' of R\&I capacity development with regards to policies, infrastructure facilities, and other contexts.

Based on their similarities and relevance, the identified measures were linked to the R\&I capacity development indices; further labelled as Key Performance Indicators (KPIs). The measures and KPIs were compiled into a spreadsheet and grouped based on their relevance and suitability to the three major themes of R\&I capacity components: "Structure, System and Policy", "Skills and Training", and "Staff".

The results of KPIs identification from the literature were discussed internally between authors. This process was aimed at removing indicators irrelevant to the research and innovation capacity assessment.

\section{B. Focus Group Discussion}

The draft version of the KPIs and measures was later presented to participants of the three-round Focus Group Discussion (FGD), which was held in Colombo, Sri Lanka. The FGD participants consisted of 24 high-profile academics from 14 institutions from 7 countries across Europe and Asia. The FGD was aimed at collecting inputs and comments to the draft KPIs and measures. The FGD session was also aimed at evaluating the relevance of the proposed indicators and measures, and defining the assessment scale of each measure. The assessment scale included the number, percentage, 'yes' or 'no' answer, and Likert scale.

Based on the comments and inputs from the FGD, the KPIs and measures were updated and finalised.

The final version was later used for the next step. Fig. 1 below shows the flow of the KPI and measures development process.

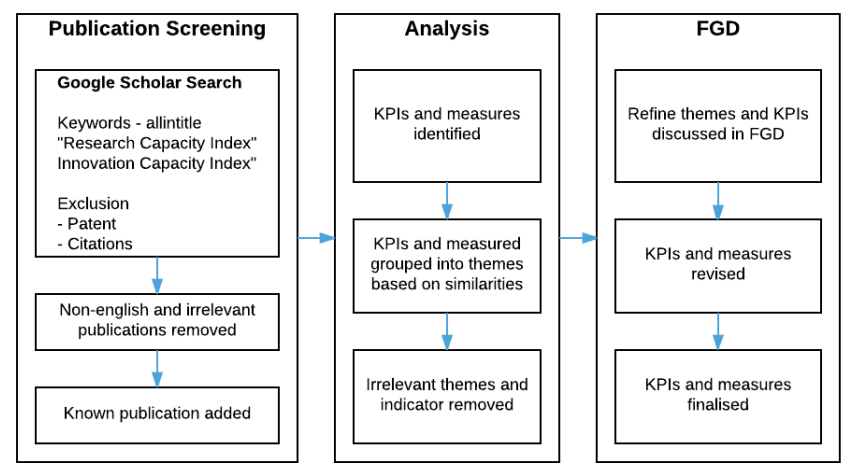

Fig. 1 KPI and measures development process

\section{Semi-Structured Interviews}

The next step of the CDF formulation involves the collection of data from various stakeholders through semistructured interviews and online questionnaire survey. Based on the established set of KPIs and measures, five sets of interview protocols were developed to identify R\&I needs, current capacities, and gaps within the context of Higher Education Institutions in Asia from five stakeholder 
categories, namely: policy makers (P) and high-level university authority (U) at the national level, university research directors and managers (D), university academic staff (A) and university research staff (R) at the university level. Sri Lanka, Thailand and Bangladesh were selected for the case study location, as the three countries are the focus partner countries of the project. The semi-structured interviews were performed by 8 teams, one representing each partner universities in Sri Lanka (3 teams), Thailand (2 teams), and Bangladesh (3 teams). The questions for the interviews were structured to obtain answers to the following issues:

- Importance of R\&I for Higher Education Institutions

- R\&I capacity building in HEIs - Current Context and Gaps

- Policies to promote R\&I in HEIs - Current Context and Gaps

- Training and Development initiatives for R\&I in HEIs - Current Context and Gaps

- 'Enablers' that support R\&I in HEIs - Current Context

- 'Barriers' that hinder R\&I in HEIs - Current Context

- Suggestions to improve R\&I in HEIs - Needs

Prior to data collection, the interview protocols were piloted amongst the project team members. Revised protocols were accordingly prepared based on the comments received from the pilot interview exercise.

The data collected from the semi-structured interviews were analysed and presented using various approach including Likert scale, the frequency of occurrence, and descriptive analysis. This allows responses to be compared and contrasted whilst at the same time provides the opportunity to showcase the in-depth qualitative analysis result.

\section{Online Baseline Survey}

Alongside the semi-structured interviews, an online survey questionnaire was also carried out to collect data from a broader audience regarding the R\&I capacity needs of the HEIs in the three case study countries. The online survey was designed to gather input from both full-time and part-time Academic and Research staff, in addition to those currently involved in/or interested in R\&I activities. The survey responses were anonymous and treated as confidential. The questionnaire survey was analysed using inferential and descriptive statistic approach, with the aid of SPSS 23.0 software.

The questionnaire survey was prepared to cover the following research questions:

- What are the critical issues associated with the R\&I activities for the development of the societal resilience to disasters?

- Are there synergies and linkages between R\&I activities and capacity advancing skill creation to enhance transformation, and what are they?

- What are the 'enablers' in the R\&I activities impacting on the capacity to advancing skill creation to enhance transformation, and the development of societal resilience to disasters?

- What are the 'barriers' in the R\&I activities impacting on the capacity to advancing skill creation to enhance transformation, and the development of societal resilience to disasters?

- What is the level of use of research methodologies and techniques for enabling research and innovation capacity strengthening for the development of societal resilience to disasters?

As with the semi-structured interviews, the online questionnaire protocol was piloted amongst the project member for comments and improvement, prior to public distribution. The final version was distributed using the Survey Monkey platform.

\section{RESULTS AND DISCUSSIONS}

\section{E. Analysis of Data}

As described in the previous section, the development of the CDF collected data from various sources and methods. At the initial stage, a qualitative systematic literature review was performed in order to identify existing indices related to the assessment of research and innovation capacity. The google scholar search resulted in 19 publications derived from 'innovation capacity index' keywords and 25 publications from the 'research capacity index'.

Further screening of the list of publications shows that most of the articles were either in non-English language or discussion subjects were not relevant to the context of R\&I capacity in higher education institutions. The majority of the identified publications were focused on R\&I capacity related to technological advancement in manufacturing and construction. Consequently, a manual search of relevant publications in the area was required to cover the gap. Four additional publications were added manually to the list from authors' personal collection of bibliographies. The ultimate result of consolidated list of publication consisted of 9 publications considered for further analysis (see Table 1)

The result of the qualitative systematic literature review suggests that there is a gap in the literature with regards to a framework for the assessment and identification of R\&I capacity in the disaster resilience related subject. It is also argued that whilst this study is limited to google scholar database; it indicates the limited publications available in this area.

The content analysis exercise of the literature resulted in the identification of measures relevant to the R\&I capacity framework. The measures included 'barriers' and 'enablers' of R\&I capacity development with regards to policies, infrastructure facilities, and other contexts. The University of Memphis [4] adopted Birdsell's model to assess the organizational capacity for research and identifies various assessment dimensions. The adopted model (Fig. 1) recognizes that capacity is affected by the ability and motivation to perform, which needs to be supported by the organisational culture. Cooke and Green [5] argue that an established culture of research in the relevant discipline is essential to positively affect the research performance of an institution. They further highlight lack of leadership, strategy or direction, and lack of 'research mindedness' as the inhibiting culture to research capacity.

Bazeley [6], on the other hand, suggests that motivation is a more critical element in staff development than the research skills, supported by positive personal characteristics 
such as persistence, initiative, and concern for advancement [7]. Supporting his view, Cooke and Green [5] also conclude that motivation to undertake research is a critical supporting element to developing research capacity. At the same time, motivation to undertake research can be cultivated through the provision of a higher level of funding for research, foster institutional alliances, and networking, incentivise private investments in public research, and by providing adequate competitive infrastructure for research [8].

TABLE I

CONSOLIDATED List OF PUBLiCATIONS

\begin{tabular}{|c|c|c|c|}
\hline $\begin{array}{l}\text { Search } \\
\text { Keywords }\end{array}$ & $\begin{array}{l}\text { Authors } \\
\text { and Year }\end{array}$ & Themes & $\begin{array}{l}\text { Study } \\
\text { Scope }\end{array}$ \\
\hline \multirow[t]{5}{*}{$\begin{array}{l}\text { Innovation } \\
\text { Capacity } \\
\text { Index }\end{array}$} & $\begin{array}{l}\text { Greenwood } \\
\text { [9] }\end{array}$ & $\begin{array}{l}\text { Innovative capacity } \\
\text { index for effective } \\
\text { open innovation }\end{array}$ & Global \\
\hline & $\begin{array}{l}\text { INSEAD } \\
{[\mathbf{1 0}]}\end{array}$ & $\begin{array}{l}\text { Mapping innovation } \\
\text { capacity }\end{array}$ & $\begin{array}{l}21 \text { natural } \\
\text { resources } \\
\text { rich } \\
\text { economies }\end{array}$ \\
\hline & $\begin{array}{l}\text { Lopez- } \\
\text { Claros and } \\
\text { Mata [11] }\end{array}$ & $\begin{array}{l}\text { Factors, policies and } \\
\text { institutions driving } \\
\text { country innovation }\end{array}$ & Global \\
\hline & $\begin{array}{l}\text { Usman and } \\
\text { Liu [12] }\end{array}$ & $\begin{array}{l}\text { Framework to } \\
\text { measure innovation } \\
\text { capacity and } \\
\text { efficiency }\end{array}$ & $\begin{array}{l}\text { South } \\
\text { Asian } \\
\text { region }\end{array}$ \\
\hline & $\begin{array}{l}\text { Wonglimpiy } \\
\text { arat [13] }\end{array}$ & $\begin{array}{l}\text { Nations innovation } \\
\text { capacity }\end{array}$ & Thailand \\
\hline \multirow[t]{4}{*}{$\begin{array}{l}\text { Authors' } \\
\text { Personal } \\
\text { Bibliograp } \\
\text { hies }\end{array}$} & $\begin{array}{l}\text { Block and } \\
\text { Mills [14] }\end{array}$ & $\begin{array}{l}\text { Assessing health } \\
\text { policy and system } \\
\text { research capacity }\end{array}$ & $\begin{array}{l}\text { Global low } \\
\text { and } \\
\text { middle- } \\
\text { income } \\
\text { countries }\end{array}$ \\
\hline & $\begin{array}{l}\text { Cooke and } \\
\text { Green [5] }\end{array}$ & $\begin{array}{l}\text { Developing nursing } \\
\text { and midwife } \\
\text { research capacity }\end{array}$ & $\begin{array}{l}\text { United } \\
\text { Kingdom }\end{array}$ \\
\hline & Jensen [8] & $\begin{array}{l}\text { Research capacity } \\
\text { of higher education }\end{array}$ & Slovak \\
\hline & $\begin{array}{l}\text { University } \\
\text { of Memphis } \\
\text { [4] }\end{array}$ & $\begin{array}{l}\text { Research capacity } \\
\text { assessment }\end{array}$ & $\begin{array}{l}\text { University } \\
\text { of } \\
\text { Memphis }\end{array}$ \\
\hline
\end{tabular}

Similarly, the importance of renewing the research infrastructure, networking and framework conditions in order to build the international competitiveness are also underlined [8]. With regards to ICT, Lopez-Claros and Mata [11] emphasises that access to and the quality of ICT infrastructure as one of the keys to improving the capacity of R\&I. They further suggest the use of ICT as indicators and supports towards innovation capacity which includes the quality of the infrastructure, government ICT usage, telephone and mobile cellular communication, and the use of internet, computers, and TV.

Based on their similarities and relevance, the identified measures were linked to the R\&I capacity development indices; further labelled as Key Performance Indicators (KPIs). The measures and KPIs were discussed internally between authors to filter out irrelevant measures, prior to further drafting and grouping based on their relevance and suitability. As many as 156 measures were identified and linked to 13 Key Performance Indicators under the three major themes of R\&I capacity components: "Structure, System and Policy", "Skills and Training", and "Staff".

At the next stage, the drafts set of KPIs and measures were consulted with participants of Focus Group Discussion. Some of the comments included the needs to define the practical meaning of 'region' as it may be interpreted differently from the geographical point of the subnational area (e.g., province, district) vs. supranational area (e.g., South Asia, North America). Similarly, the terms 'institutional' and 'students' also need to be defined whether they are meant for the faculty level, department, or university level, and whether it is undergraduate, postgraduate, or research students. Based on the results of the FGD, the revised version of the KPIs and measures consisted of 148 measures, which are linked to 21 KPIs and are grouped into three themes as shown in TABLE. The assessment scales of each measure were also defined in the FGD.

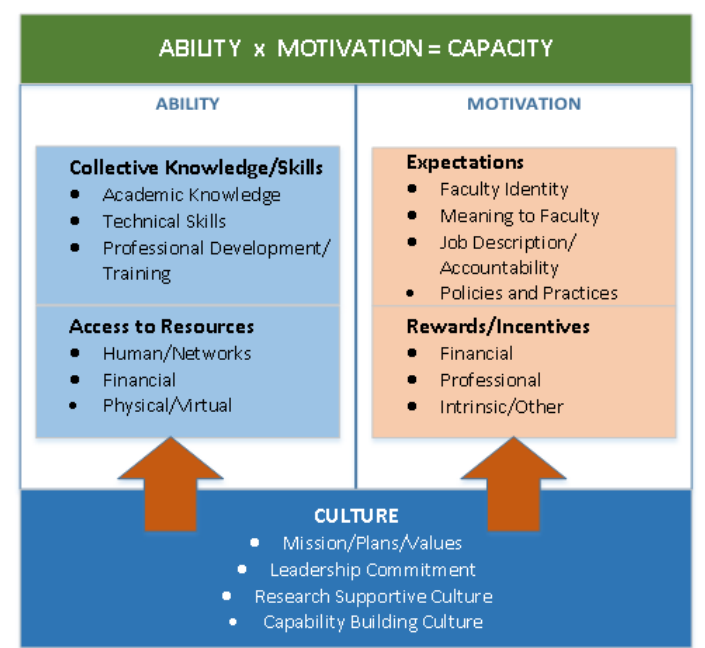

Fig. 1 Adaptation of the Birdsell, et al. box model (University of Memphis, 2013)

The finalized version of the KPIs and measures were further used as the basis for the semi-structured interviews and an online survey. In total, 213 interviews were carried out by the 8 partner university teams within the 6-week duration. The analysis of interview highlights several crucial issues related to the R\&I capacity of the HEIs in the case study countries.

In Bangladesh, it was identified that the R\&I for the sustainable development and strengthening the resilience of communities as a universal and utmost significance issue, as all respondents unanimously supported R\&I as the priority agenda. Even though it was agreed that research is important as a way to produce evidence that helps to shape the policy and innovation as well as for idea generation, the respondents' point of view and argumentation appeared to be different in some respects. For instance, one respondent from the national policymaker level mentioned research as a tool for making future-oriented and visionary decisions and implicitly emphasized the importance of applied research.

Countering this argument, however, another respondent from the university level manager argued that "basic scientific research should be prioritized". It was acknowledged that the different foci of research areas had been identified from diverse angles which could be assumed 
happening due to the diverse academic background and professional experiences of the respondents. Furthermore, whilst all respondents in Bangladesh acknowledged R\&I capacity as an important issue, it was also eminent that there is a big gap between the research and innovation aspiration and the research capacity and coordination.

TABLE II

SUMMARY OF KPIS TO RESEARCH AND INNOVATION CAPACITY IN DISASTER RESILIENCE

\begin{tabular}{|c|c|}
\hline Themes & KPI \\
\hline \multirow{9}{*}{$\begin{array}{l}\text { Structure, } \\
\text { System, } \\
\text { and Policy }\end{array}$} & 1. Access to infrastructure \\
\hline & 2. Access to international research community \\
\hline & 3. $\quad$ Institutional incentives \\
\hline & 4. R\&I enabling environment \\
\hline & 5. Research capacity and intensity \\
\hline & $\begin{array}{ll}6 . & \text { Research funding and grant } \\
\end{array}$ \\
\hline & $\begin{array}{l}\text { 7. Research in partnership with external } \\
\text { stakeholders }\end{array}$ \\
\hline & 8. $\quad$ Research infrastructure \\
\hline & 9. University innovation activities \\
\hline \multirow{7}{*}{$\begin{array}{l}\text { Skills and } \\
\text { Training }\end{array}$} & 10. Access to infrastructure \\
\hline & 11. Access to international research community \\
\hline & 12. Publication quality and intensity \\
\hline & 13. Research capacity and intensity \\
\hline & 14. Research funding and grant \\
\hline & $\begin{array}{l}\text { 15. Research in partnership with external } \\
\text { stakeholders }\end{array}$ \\
\hline & 16. University innovation activities \\
\hline \multirow{5}{*}{ Staff } & 17. Research capacity and intensity \\
\hline & 18. Research capacity and intensity \\
\hline & $\begin{array}{l}\text { 19. Research career development and staff } \\
\text { renewal }\end{array}$ \\
\hline & $\begin{array}{l}\text { 20. Research in partnership with external } \\
\text { stakeholders }\end{array}$ \\
\hline & 21. Staff quality \\
\hline
\end{tabular}

In Thailand, most respondents agreed that R\&I can construct new knowledge and innovation that can be used for teaching \& learning in HEIs, solve the problem in real life, and develop products for commercial sale. It was suggested that the most important 'enablers' of R\&I capacity development were national policy, sufficient budget allocation, the availability of staff and resources, and skills and training development program.

Clearly defined, well-supported, flexible and tangible national policy was deemed as the most important enabler as it would express the R\&I direction of the country. It would also, in turn, determine funding support towards R\&I. For instance, as soon as the government announced a special fund for increasing R\&I capabilities for the National Research University, several universities in Thailand set their goal to be a research university in order to get a sharing of the fund. The research grant was also highlighted as an important enabler of R\&I. It was argued that the increased research grant allocation will attract academics towards research and will, therefore, increase the number of researchers performed. At the same time, however, it was admitted that research grant alone could not support R\&I in HEIs, as good quality staff, and adequate resources were considered as similarly important 'enablers'. The latter 'enablers' required continuous skills development and training programme.
However, it was also revealed that training and capacity development programmes were generally held only once a year due to lack of budget allocation. Also, even though the respondents in Thailand suggested that R\&I capacity as a very important issue for HEIs, the disaster resilience (DR) subject has not been sufficiently supported by the government. There was no direct policy related to DR, and no budget allocation has been provided directly to DR related research topic.

In Sri Lanka, the respondents suggest that R\&I should result in improvement in knowledge and learning and be used to address real problems and needs of the society. It was also highlighted that there should be a better mechanism in place to evaluate, guide, steer and monitor the research activities towards shaping the policy and determining future actions. The importance of research designing, planning, and collaborative works was generally undervalued. It was also noted that there was a lack of continuity in the research programme, resulting in ad-hoc changes that were detrimental to the sustainability of research in the long term. One of the major issues was the perennial problem of lack of resources for funding, which needed to be addressed systematically.

In general, stakeholder awareness on R\&I activities, provision of skills acquisition programme, promotion of Ph.D. and Postdoctoral programmes, and the introduction of permanent research cadres with attractive packages to the university system was identified as the important enables of R\&I capacity development in Sri Lanka.

Running alongside the semi-structured interviews, the online questionnaire survey collected 530 responses with the aid of Survey Monkey platform. The survey revealed that a number of universities in the case study countries had developed research portfolio and associated activities related to disaster resilience and sustainable development. The research portfolio included Health, demographic change, and well-being; food security; sustainable agriculture, marine and maritime; the bio-economy; secure, clean and efficient energy; smart, green and integrated transport; Climate action, resource efficiency and raw materials; and inclusive, innovative and secure societies.

The survey also identified a number of 'enablers' and 'barriers' to R\&I capacity development. The survey highlights 'funding' as the most critical 'enablers', highlighting 'availability of grants and scholarships', 'support by funding bodies', 'human resources' (i.e., increasing the availability of staff, training, and equipment to the researcher). It was also emphasized that the identified 'enablers' need to be supported by up-to-date policies. The 'most important' and 'important' enablers identified in the survey are listed in the

On the other hand, 'barriers' to R\&I capacity development identified included lack of R\&I skills, lack of updated research regulations, lack of policy implementation, unclear/ inadequate policies on R\&I, and low success rate of research bidding. More details on the list of identified 'barriers' is shown in TABLE .

\section{F. Capacity Development Framework (CDF)}

Based on the analysis of data collected from various sources discussed previously, a capacity development 
framework was formulated. The CDF is regarded as an effective vehicle to develop supporting research infrastructure, prepare researchers to undertake advanced, world-class and innovative, multi- and interdisciplinary research, and increase international cooperation among higher education institution across the case study countries.

The proposed CDF underpins a major strategic approach to strengthen research and innovation $(R \& I)$ capacity for the development of societal resilience to disasters in HEIs of the case study countries. The framework has been developed by and for the research community working in higher education as a tool to overcoming 'barriers' and executing 'enablers', leading to comprehensive development through six concurrent and integrated lenses, as illustrated in Fig. 2.

It is suggested that HEIs need to adapt and adopt each of these lenses to match the context of each institution, and guided by the requirement to attain the cross-cutting capacity development at the country level. Knowledge sharing among stakeholders is affected by the social capital and individual factors [15]. Accordingly, depending on the individual, institutional and national needs, additional lenses might be required.

The six lenses - policy, skills and training, staff, funding, infrastructure, and cross-cutting, collectively provide a comprehensive strategic roadmap of the key interventions and future actions and attributes distinctively developed by researchers and associates that are the core beneficiaries. Evidently, it appears that each lens highlights key category for current and future environment to strengthen research and innovation (R\&I) capacity for the development of societal resilience to disasters in HEIs.
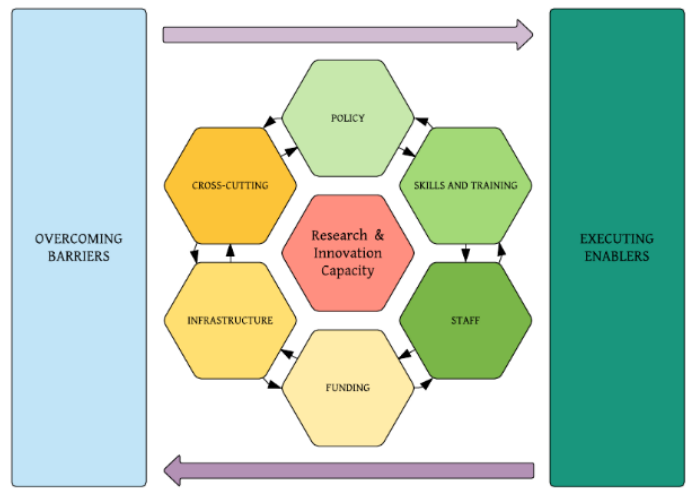

Fig. 2 Capacity development framework (CDF)

In the highly competitive environment of R\&I activities related to DR in HEIs, the six lenses are argued as keys for individual and institutional towards enhancing transformations, increasing capacities and addressing challenges of DR and building international cooperation. The lenses are defined as follows:

- Policy - Involving university experts in policymaking and developing policies to stimulate investment in research and innovation.

- Skills \& training - The knowledge, intellectual abilities, and techniques to do research as well as govern and organise the research process with professionalism.

- Staff - Engagement, influence, and impact to ensure the wider impact of research is achieved with an increase in personal qualities and effectiveness.
- Funding - Knowledge of funding sources, generation, management and ability to develop funding proposal working between both academics and non-academics.

- Infrastructure - Access, quality, and level of uptake and use of ICT and communication infrastructure for R\&I.

- Cross-cutting - Engagement, influence and the wider impact on economic, productivity and society and having a culture of global citizenship.

In line with the suggested lenses, Huenneke [16] highlights seven essentials to sustain research capacity which include:

- Institutional investment for recruiting new faculty members.

- Programs attending to career development plans for all, not just for junior faculty, and adapt plans for the particular institution and programmes.

- Permitting and supporting more diverse team structures.

- Attending to researchers' longer-term connections to and opportunities within the institution.

- Deliberate attention to inviting advisory committee members and institutional leaders to ensure the connections are deep and the supports are genuine.

- Frank acknowledgement of differing institutional cultures and values, and flexibility in choosing relevant, important metrics for program evaluation and management.

- Transition and succession planning should be considered from the start, to anticipate the impact of personnel turnover.

TABLE III

'ENABLERS' TO CARRY OUT R\&I ACTIVITIES

\begin{tabular}{|c|c|c|}
\hline Category & ENABLERS & Importance \\
\hline Funding & $\begin{array}{l}\text { Availability of grants and } \\
\text { scholarships }\end{array}$ & $\begin{array}{l}\text { Most } \\
\text { important }\end{array}$ \\
\hline Funding & Support by funding bodies & $\begin{array}{l}\text { Most } \\
\text { important }\end{array}$ \\
\hline Policy & $\begin{array}{l}\text { Availability of up-to-date } \\
\text { policies for R\&I }\end{array}$ & $\begin{array}{l}\text { Most } \\
\text { important }\end{array}$ \\
\hline $\begin{array}{l}\text { Human } \\
\text { resources }\end{array}$ & $\begin{array}{l}\text { Availability of research } \\
\text { cadres/associate/assistantships }\end{array}$ & $\begin{array}{l}\text { Most } \\
\text { important }\end{array}$ \\
\hline Policy & Government support for R\&I & Important \\
\hline $\begin{array}{l}\text { Infrastruct } \\
\text { ure }\end{array}$ & $\begin{array}{l}\text { Availability of resources (e.g., } \\
\text { equipment and research tools) }\end{array}$ & Important \\
\hline $\begin{array}{l}\text { Human } \\
\text { resources }\end{array}$ & $\begin{array}{l}\text { Support by the administrators } \\
\text { and administrative staff }\end{array}$ & Important \\
\hline Policy & $\begin{array}{l}\text { Availability of policies that } \\
\text { support R\&I (National, } \\
\text { regional or university level) }\end{array}$ & Important \\
\hline $\begin{array}{l}\text { Human } \\
\text { resources }\end{array}$ & $\begin{array}{l}\text { Availability of staff (academic } \\
\text { and research staff) }\end{array}$ & Important \\
\hline $\begin{array}{l}\text { Human } \\
\text { resources }\end{array}$ & $\begin{array}{l}\text { Availability of training for } \\
\text { R\&I }\end{array}$ & Important \\
\hline $\begin{array}{l}\text { Human } \\
\text { resources }\end{array}$ & $\begin{array}{l}\text { Stimulating research } \\
\text { environment within the } \\
\text { Institution }\end{array}$ & Important \\
\hline $\begin{array}{l}\text { Human } \\
\text { resources }\end{array}$ & $\begin{array}{l}\text { Favourable working conditions } \\
\text { (fair workload for staff) }\end{array}$ & Important \\
\hline $\begin{array}{l}\text { Infrastruct } \\
\text { ure }\end{array}$ & $\begin{array}{l}\text { Availability of infrastructure } \\
\text { (ICT facilities, research } \\
\text { centres) }\end{array}$ & Important \\
\hline
\end{tabular}


TABLE IV

'BARRIERS' TO CARRY OUT R\&I ACTIVITIES

\begin{tabular}{|c|c|c|}
\hline Category & Barriers & Importance \\
\hline $\begin{array}{l}\text { Human } \\
\text { resources }\end{array}$ & Lack of R\&I skills & $\begin{array}{l}\text { Very } \\
\text { important }\end{array}$ \\
\hline Policy & $\begin{array}{l}\text { Lack of updated research } \\
\text { regulations }\end{array}$ & $\begin{array}{l}\text { Very } \\
\text { important }\end{array}$ \\
\hline Policy & Lack of policy implementation & $\begin{array}{l}\text { Very } \\
\text { important }\end{array}$ \\
\hline Policy & $\begin{array}{l}\text { Unclear / inadequate policies on } \\
\text { R\&I }\end{array}$ & $\begin{array}{l}\text { Very } \\
\text { important }\end{array}$ \\
\hline Funding & $\begin{array}{l}\text { Low success rate of research } \\
\text { bidding }\end{array}$ & $\begin{array}{l}\text { Very } \\
\text { important }\end{array}$ \\
\hline Funding & $\begin{array}{l}\text { Low pay and under-resourcing push } \\
\text { many academics into consultancy } \\
\text { and private teaching arrangements, } \\
\text { rather than research }\end{array}$ & $\begin{array}{l}\text { Very } \\
\text { important }\end{array}$ \\
\hline $\begin{array}{l}\text { Cross- } \\
\text { cutting }\end{array}$ & Lack of industry links & $\begin{array}{l}\text { Very } \\
\text { important }\end{array}$ \\
\hline $\begin{array}{l}\text { Cross- } \\
\text { cutting }\end{array}$ & $\begin{array}{l}\text { Lack of opportunities for } \\
\text { international collaboration }\end{array}$ & $\begin{array}{l}\text { Very } \\
\text { important }\end{array}$ \\
\hline $\begin{array}{l}\text { Cross- } \\
\text { cutting }\end{array}$ & $\begin{array}{l}\text { Lack of transparency, rigour, and } \\
\text { efficiency of research governance }\end{array}$ & $\begin{array}{l}\text { Very } \\
\text { important }\end{array}$ \\
\hline $\begin{array}{l}\text { Human } \\
\text { resources }\end{array}$ & $\begin{array}{l}\text { Growing number of students } \\
\text { increases the teaching and } \\
\text { administration workloads with less } \\
\text { space for research. }\end{array}$ & $\begin{array}{l}\text { Very } \\
\text { important }\end{array}$ \\
\hline $\begin{array}{l}\text { Human } \\
\text { resources }\end{array}$ & Heavy teaching workload & $\begin{array}{l}\text { Very } \\
\text { important }\end{array}$ \\
\hline $\begin{array}{l}\text { Human } \\
\text { resources }\end{array}$ & $\begin{array}{l}\text { Lack of skills in managing research } \\
\text { projects }\end{array}$ & Important \\
\hline $\begin{array}{l}\text { Human } \\
\text { resources }\end{array}$ & Lack of peer mentoring and support & Important \\
\hline $\begin{array}{l}\text { Human } \\
\text { resources }\end{array}$ & $\begin{array}{l}\text { Lack of research networking and } \\
\text { integration }\end{array}$ & Important \\
\hline $\begin{array}{l}\text { Human } \\
\text { resources }\end{array}$ & $\begin{array}{l}\text { Lack of training and development } \\
\text { on R\&I }\end{array}$ & Important \\
\hline $\begin{array}{l}\text { Human } \\
\text { resources }\end{array}$ & $\begin{array}{l}\text { Lack of motivation to carry out R\&I } \\
\text { activities }\end{array}$ & Important \\
\hline $\begin{array}{l}\text { Human } \\
\text { resources }\end{array}$ & $\begin{array}{l}\text { Lack of early career research } \\
\text { support }\end{array}$ & Important \\
\hline Policy & $\begin{array}{l}\text { Lack of strategic cross-cutting } \\
\text { research initiatives to promote } \\
\text { fundamental and interdisciplinary } \\
\text { activities }\end{array}$ & Important \\
\hline Funding & $\begin{array}{l}\text { Lack of incentives to staff (academic } \\
\text { and research staff) }\end{array}$ & Important \\
\hline Funding & $\begin{array}{l}\text { Lack of funding (budget allocation, } \\
\text { scholarships, and research grants) }\end{array}$ & Important \\
\hline $\begin{array}{l}\text { Cross- } \\
\text { cutting }\end{array}$ & $\begin{array}{l}\text { Lack of multi-disciplinary team } \\
\text { approach }\end{array}$ & Important \\
\hline $\begin{array}{l}\text { Human } \\
\text { resources }\end{array}$ & $\begin{array}{l}\text { Individual research fellowship and } \\
\text { training often do not translate into } \\
\text { career support and organisational } \\
\text { support of a research culture }\end{array}$ & Important \\
\hline $\begin{array}{l}\text { Infrastru } \\
\text { cture }\end{array}$ & $\begin{array}{l}\text { Lack of resources (e.g., research } \\
\text { tools, laboratories, equipment) }\end{array}$ & $\begin{array}{l}\text { Not } \\
\text { important }\end{array}$ \\
\hline $\begin{array}{l}\text { Infrastru } \\
\text { cture }\end{array}$ & $\begin{array}{l}\text { Inadequate infrastructure to carry } \\
\text { out R\&I activities }\end{array}$ & $\begin{array}{l}\text { Not } \\
\text { important }\end{array}$ \\
\hline $\begin{array}{l}\text { Infrastru } \\
\text { cture }\end{array}$ & Lack of research space & $\begin{array}{l}\text { Not } \\
\text { important }\end{array}$ \\
\hline $\begin{array}{l}\text { Human } \\
\text { resources }\end{array}$ & $\begin{array}{l}\text { Lack of support from the } \\
\text { administrative staff }\end{array}$ & $\begin{array}{l}\text { Not } \\
\text { important }\end{array}$ \\
\hline $\begin{array}{l}\text { Human } \\
\text { resources }\end{array}$ & $\begin{array}{l}\text { Lack of administrative skills to } \\
\text { support the R\&I activities }\end{array}$ & $\begin{array}{l}\text { Not } \\
\text { important }\end{array}$ \\
\hline
\end{tabular}

\section{CONCLUSION}

This paper presented a discussion on the 'barriers' and 'enablers' of R\&I in the HEIs, which leads to the formulation of the proposed capacity development framework. The framework provides suggestions that might be applied to develop the research and innovation capacity of researchers and institutions, both at institutional and national levels and would collectively have an impact on the regional level. It will eventually equip the HEI's scientific/academic, management, administrative and technical staff with enhanced competencies and skills, whilst increasing the management, governance and innovation capacities.

The proposed capacity development framework serves as a guide for strategic progression in enhancing R\&I capacities of the HEIs. The concurrent and integrated lenses focus on overcoming barriers and executing 'enablers' of R\&I activities related to disaster resilience in HEIs that can be directed to develop research infrastructure, prepare researchers to undertake advanced, world-class and innovative, multi- and interdisciplinary research, and increase international cooperation among higher education. These lenses also have the capacity to explore, promote and initiate opportunities for fruitful university/industry partnerships. In doing so, the CDF will provide the link between the research and the public, helping to reinforce the connection between education and society.

\section{ACKNOWLEDGEMENT}

This study is part of the capacity building project called ASCENT. The project is co-funded by the European Union through its Erasmus plus scheme. The European Commission support for the production of this publication does not constitute an endorsement of the contents which reflects the views only of the authors, and the Commission cannot be held responsible for any use which may be made of the information contained therein.

\section{REFERENCES}

[1] Nguyen, T.L.H., Building human resources management capacity for university research: The case at four leading Vietnamese universities. Higher Education, 2016. 71(2): p. 231-251.

[2] Crossley, M., Comparative Education and Research Capacity Building: Reflections on International Transfer and the Significance of Context. Journal of International and Comparative Education (JICE), 2017: p. 4-12, 2232-1802.

[3] Alenazi, S.R. and Kamsuriah, Record Duplication Detection in Database: A Review. 2016. Vol. 6. 2016.

[4] University of Memphis, Research Capacity Assessment Taskforce Report. 2013.

[5] Cooke, A. and B. Green, Developing the research capacity of departments of nursing and midwifery based in higher education: A review of the literature. Journal of Advanced Nursing, 2000. 32(1): p. 57-65.

[6] Bazeley, P., From vocational college to new university: The research profile and development needs of academic staff in a period of transition. Higher education research and development, 1994. 13(2): p. 121-132.

[7] Babu, A.R. and Y. Singh, Determinants of research productivity. Scientometrics, 1998. 43(3): p. 309-329.

[8] Jensen, H.T., et al., The Slovak Higher Education System and its Research Capacity, in EUA SECTORAL REPORT. 2008, European University Association. 
[9] Greenwood, D.G., Collaborate to Innovate: Innovative Capacity Index for Effective Open Innovation. 2010, University of Maryland University College: Ann Arbor. p. 75.

[10] INSEAD, Innovation Efficacy Index: Mapping Innovation Capacity in 21 Natural Resource Rich Economies.

[11] Lopez-Claros, A. and Y.N. Mata, The Innovation Capacity Index: Factors, Policies, and Institutions Driving Country Innovation, in The Innovation for Development Report 2009-2010. 2010, Springer. p. 3-65.

[12] Usman, K. and Z. Liu, Innovation Index Framework to Measure the Innovation Capacity and Efficiency of SAARC Countries. European Journal of Social Sciences, 2015. 46(3): p. 325-338.
[13] Wonglimpiyarat, J., Innovation index and the innovative capacity of nations. Futures, 2010. 42(3): p. 247-253.

[14] Block, M.A.G. and A. Mills, Assessing capacity for health policy and systems research in low and middle income countries*. Health Research Policy and Systems, 2003. 1(1): p. 1.

[15] Baker, M.B. and Z. M.Yusof, The Effects of Social Capital and Individual Factors on Knowledge Sharing Among ERP System Users. 2016. Vol. 6. 2016.

[16] Huenneke, L.F., et al., Key Strategies for Building Research Capacity of University Faculty Members. Innovative Higher Education, 2017. 